\title{
HYDROLOGY OF MIRE ECOSYSTEMS IN CENTRAL WEST SIBERIA: THE MUKHRINO FIELD STATION
}

\author{
Bleuten W., Filippov I. \\ w.bleuten@geo.uu.nl
}

The hydrology of mires (pristine peatland ecosystems) hardly has been analyzed quantitatively. The general idea, that mires can retain precipitation water ('sponge effect') has never been proved by real field data. Missing data for evaluation of these properties are actual evapotranspiration, water conductivity and interception of rainwater by peatland mosses and peat layers below.

The newly opened Mukhrino Field Station, located in the centre of West Siberia at the margin of a giant mire complex gave the opportunity to start quantitative hydrological research. Water stage dynamics in mires has been recorded with pressure loggers in mires and in lysimeters to analyse the evapotranspiration, interception and the water balance. Air and water temperature and precipitation has been recorded simultaneously.

First results from data gathered in the summer of 2008 have been elaborated. By 1-Dimensional modelling interception appeared to be the most important water loss for mires. As expected, mostly snowmelt determined discharge dynamics of the studied peatland catchment area. Rainfall events resulted in relatively fast response in catchment discharge. The so-called 'sponge effect' of mire systems could not be verified this time.

The future research will focus on snowmelt effect on hydrographs. By 3Dimensional modelling the relation between land unit type ('mire type') and discharge dynamics will be analyzed more thoroughly.

\section{Concepts of mire hydrology}

Pristine peatland ecosystems ("mires") can develop and sustain under conditions of precipitation access over evapotranspiration, and lack of efficient drainage. Mires are if high importance because they can sequestrate carbon from atmosphere while forming peat. Plants (trees, shrubs, herbs, mosses and lichens) assimilate atmospheric carbon dioxide for biomass production. This biomass will sooner (leaf tissue) or later (wood) become dead organic matter (DOM), which in turn will be subject to decomposition. In places where, by low water conductivity of the soil and or by high precipitation intensity, snow melt water and rainwater form ponds and flow over land to the nearest river channel. This overland flow will me be more pronounced when the surface relief and drainage density are small. Low water conductivity can be caused by small grain size of 
the mineral soil material (e.g. clay) or the presence of impermeable layers (e.g. ice layers in permafrost soil). By the decay of DOM small particles of organic matter may clog the pores of soil material, which result in low conductivity, even of initially high permeable soil material as sand and loam. If, during a great part of the year, the top of the soil remains wet by high water level, decomposition of DOM is slow and the topsoil becomes gradually less permeable. This process is self-strengthening, because the wet conditions pertain and a greater part of the yearly produced DOM ends in an environment (almost) without oxygen, where decomposition is very slow and as a result a part of DOM gradually changes into peat. If the environment is not drained, every year a new layer of peat will be formed. The swamp ecosystems more and more become separated from the mineral soil and, even in dry summer periods, become dependent of precipitation water. The initial swamp changes into mires (fens and oligotrophic bogs), where herbs and mosses play a mayor role in biomass production and peat formation [Bleuten et al., 2006].

At the margins of new mire complexes biomass productivity can be higher compared to central parts while nutrient supply form the (nearer) mineral soil is much higher. This difference in growth rate results in further flattening of the surface relief and by that gives a positive feedback to further mire development both vertical and in space.

Within oligotrophic bogs two main mire types will develop: the 'ryam" type (ombrotrophic bog mire with pine-low shrubs-sphagnum vegetation) with radial outflow of overland flow and the stagnant or through-flow 'hollow' types (oligotrophic mire with a vegetation of low sedges-sphagnum). Where overland flow occurs in unilateral direction, 'ridge-hollow' complexes can develop. The ridge mires of these complexes are comparable to ryam mires. Ryam mires consist of a micro relief of sphagnum hummocks and furrows in between.

The permanent water level is generally several decimeters below the sphagnum moss surface, close to the furrow bottoms. The partly aerated zone between moss surface and permanent water level is called acrotelm and the permanent saturated zone below the water table has been named acrotelm. These two layers differ substantially. The acrotelm zone consists of partly standing sphagnum stems, which can retain substantially amounts of water. By gravity the density of the layer of Sphagnum stems increases downward and by that the porosity decreases. By decomposition of DOM in the oxygen rich acrotelm (and in the upper part of the catotelm) carbon dioxide $\left(\mathrm{CO}_{2}\right)$ is emitted to the atmosphere. The acrotelm, consisting of partly decomposed organic 
material (peat), lacks oxygen almost completely. By anoxic peat decay (one order slower than in the acrotelm zone) methane $\left(\mathrm{CH}_{4}\right)$ is emitted to the atmosphere. The water conductivity of peat is very low and decreases from the top of the catotelm downward further.

Hollow mires have only thin acrotelm or lack such zone completely. The water table is close or at the surface and Sphagnum and sedges form floating mats ('quack mires'). Permeability of hollow mires is relative high but decreases rapidly from 1-1.5 m depth where 'hollow' peat is formed. In overall it can be said that water conductivity is lower in ryam (and ridges) compared to hollows at all depths below the mire surface.

In particular horizontal conductivity of mires is several orders higher than vertical conductivity [Ivanov, 1981]. This means that most of the precipitation excess water and of snowmelt water will discharge as overland flow (above and between the plants and mosses) or as subsurface flow (through the upper parts of hollow catotelm). The water flow across ridge-hollow complexes is determined by the width of ridges, which retard through-flow of water by relative low conductivities [Eppinga et al., 2008].

In hydrological studies peatland mires are expected to have a 'sponge effect', by their ability to store large quantities of water. This concept of hydrological properties may be valid for the long term $\left(10^{2}-10^{3}\right.$ years $)$, but not for prediction of the discharge (stage) effects of snow melt or of rainstorm events. The complete water saturated peat body cannot store much water. Small water table rise results in enhanced overland flow. On the other hand, the spatial pattern of mires with different hydrological properties can retain water by temporarily ponding.

The values of porosity, permeability and water conductivity of acrotelm and catotelm zones is not elaborated quantitatively to date. For prediction of water retention and by that for water stage dynamics in rivers discharging water from catchment areas with large contribution of peatland water such parameters are indispensable.

The water discharge dynamics of a peatland catchment area can be calculated from the general water balance equation (Eq.1):

$$
Q=\sum^{n} A_{i} \cdot\left(P-f_{i} \cdot E_{o}-I_{i}-S_{i}-G_{i}\right) \cdot t^{-1}
$$

Eq.1 
Where: Q: water discharge, A: surface area of mire type (i), P: precipitation (snow included), Eo: potential evaporation of open water, f: evaporation reduction factor, I: interception of precipitation water, S: storage, G: infiltration to groundwater, t: time step. Dimensions: $\mathrm{Q}$ in $\mathrm{m}^{3} \mathrm{~s}^{-1}, \mathrm{~A}$ in $\mathrm{m}^{2} ; \mathrm{P}, \mathrm{E}, \mathrm{I}, \mathrm{G}$ and $\mathrm{S}$ in $\mathrm{m}, \mathrm{t}$ in $\mathrm{s}$.

Evapotranspiration, interception and groundwater infiltration are difficult to measure. Evaporation can me modeled from heat balances (eddycovariance) or measured with lysimeters, which are small enclosures of surface water or mires. Evapotranspiration is dependent on vegetation type. In particular the relative leaf surface area divided by the surface area ('leaf area index': LAI) define the mire type dependent evaporation reduction factor (which can be >1). LAI data of West Siberian taiga mire types are not available to date. The sphagnum mosses, which make most of the vegetation cover, lack roots. They use precipitation water captured in the standing vegetation ('interception'). Infiltration of water to groundwater depends on infiltration capacity (Ic) of the (peat) soil and further on the water saturated conductivity (Ks). Both Ic and Ks are not available to date. However, the storage factor of the water balance (Eq. 1) can be calculated (by iterations) from the water stage variation at measurement sites and data of precipitation and evapotranspiration.

With a well-validated water balance model, the peatland discharge for any area with comparable mire types can be predicted from surface areas of mire types and precipitation.

\section{The Mukhrino Field Station (MFS)}

The field site if located ca $22 \mathrm{~km} \mathrm{SW}$ of the town Khanty-Mansiysk (Fig. 1) in the centre of West Siberia $\left(\mathrm{N} 60,9^{\circ}, \mathrm{E} 68,7^{\circ}\right.$ and is situated in a mixed forest on mineral ground at the margin of a small stream, which is a left bank tributary to the big Irtysh river. To the $\mathrm{S}, \mathrm{SW}, \mathrm{W}, \mathrm{NW}$ and $\mathrm{N}$ are poor Sphagnum bogs continuing 30, 80, >100, 7 and $3 \mathrm{~km}$ respectively. In SE, E and NE direction are high mixed forests present up to 3, 4, and $3 \mathrm{~km}$ respectively. At greater distance in directions SE-E-NE-N the very wide $(10-40 \mathrm{~km})$ floodplain of rivers $\mathrm{Ob}$ and Irtysh is present. The floodplain floods yearly in June-July, sometimes even in August.

The bog complex consists of ombrotrophic raised sphagnum bogs, in Russian named 'ryam', patterned bogs of ridges and elongated hollows throughflow poor fens and shallow water tracks. Peat thickness is $2-4.5 \mathrm{~m}$. (Figures 2 - 5). 


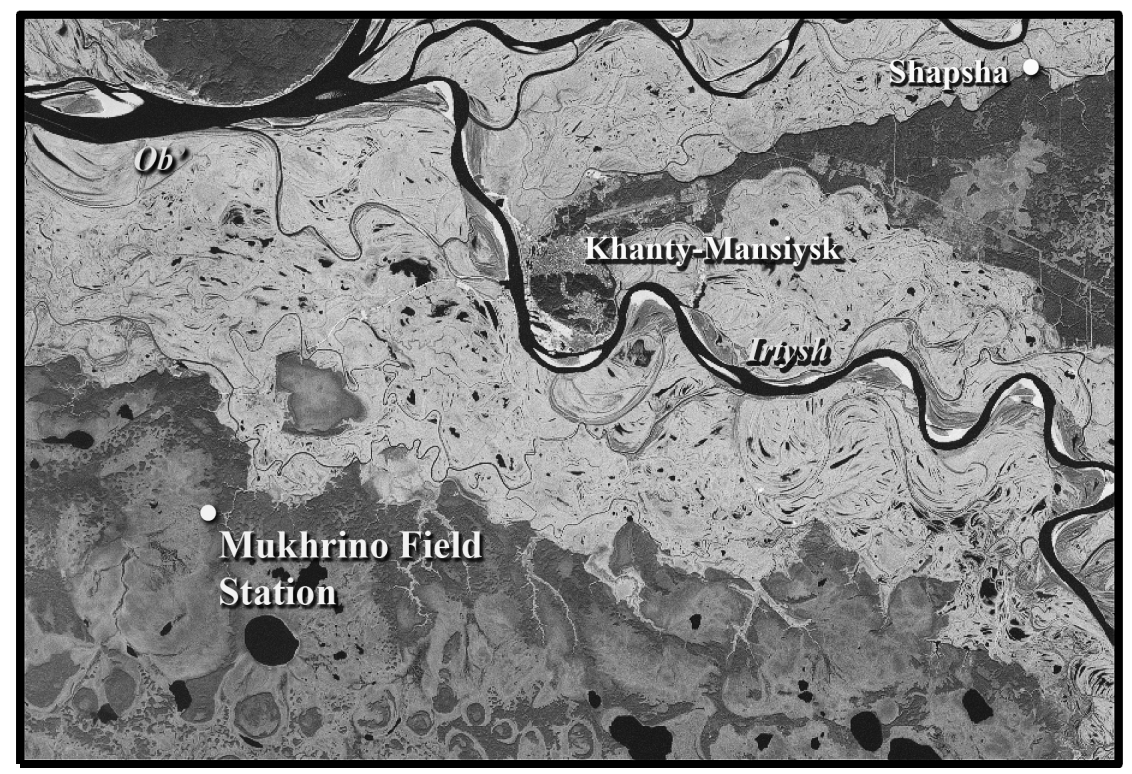

Fig. 1. Location of "Mukhrino Field Station (MFS)"

Permafrost is absent in the area, water level in hollows is at the surface and in ridges and ryam 20-50 $\mathrm{cm}$ below the Sphagnum surface (Acrotelm thickness $20-50 \mathrm{~cm}$ ). The site is representative for the West Siberian plain mires of the (middle) Taiga zone.

A stream fed only by runoff from the giant peat-bog complexes offers good opportunities for hydrological measurements. A weir (Fig. 6) has been constructed and a series of water level loggers has been installed upstream of the weir (Fig. 2) for monitoring the water level and for dynamic discharge modelling of the bog catchment.

\section{Goals for hydrological research at the MFS}

- To estimate the seasonal water retention by mires

- To estimate parameter values for hydrological modeling: porosity, water conductivity, permeability and evapotranspiration

- To analyze and model water discharge dynamics by snowmelt, rain events

- To predict the possible effects of mire hydrology on (Irtysh and Ob) river stage and discharge dynamics 


\section{Methods applied in summer 2008}

Recording of water discharge from well defined 'peatland catchment areas' near the MFS was made with standard weir(s), using discharge-stage equations calibrated with 'hand' measurements and upstream water level stage recordings with pressure loggers (Diver). With tubes (4 $\mathrm{m}$ long, at the upper 1 $\mathrm{m}$. perforated; diameter $0.06 \mathrm{~m}$.), the water level was recorded at half hour intervals, with pressure loggers (Diver), monthly calibrated with acoustic " hand' measurements. Atmospheric pressure was recorded separately with a pressure logger ('Atmo-Diver') placed $0.2 \mathrm{~m}$ above the mire surface. Half hour pressure data were corrected with the atmospheric pressure data and averaged to $24 \mathrm{hr}$ periods. Relative elevation of tubes, the weir height and 2 transects uphill across the peatland has been done with GPS (RADAC). Precipitation was recorded with an tipping bucket rain gage with event logger (Hobo) placed $1 \mathrm{~m}$ above the mire surface. The Hobo device, which also recorded hourly air temperature, was placed ca $100 \mathrm{~m}$ South from the weir. Tip-event data have been recalculated to daily data. $\left(\mathrm{mmd}^{-1}\right)$ Evapotranspiration was measured using closed lysimeters (buckets with diameter: $0.345 \mathrm{~m}$, depth: $0.275 \mathrm{~m}$ ) placed into the mire with the open surface at about the surrounding level. The water level inside the lysimeter was measured with a pressure logger (Diver). One lysimeter contains only water (p07), a second one contains water and a $0.15 \mathrm{~m}$ thick floating mat of sedge-sphagnum (p06).

\section{Results of summer season 2008}

\section{Precipitation}

Precipitation and temperature data has been acquired for the period July $20^{\text {th }}-$ September $28^{\text {th }}$ in 2008 (Fig. 7). For these period of 71 days in total 113 $\mathrm{mm}$ of rain precipitation (average: $1.6 \mathrm{mmd}^{-1}$ ) has been recorded. This amount is about the normal precipitation for this time of the year. Besides some short events, four substantial rain periods occurred around 1/8, 10/8, 30/8 and 9/9. 


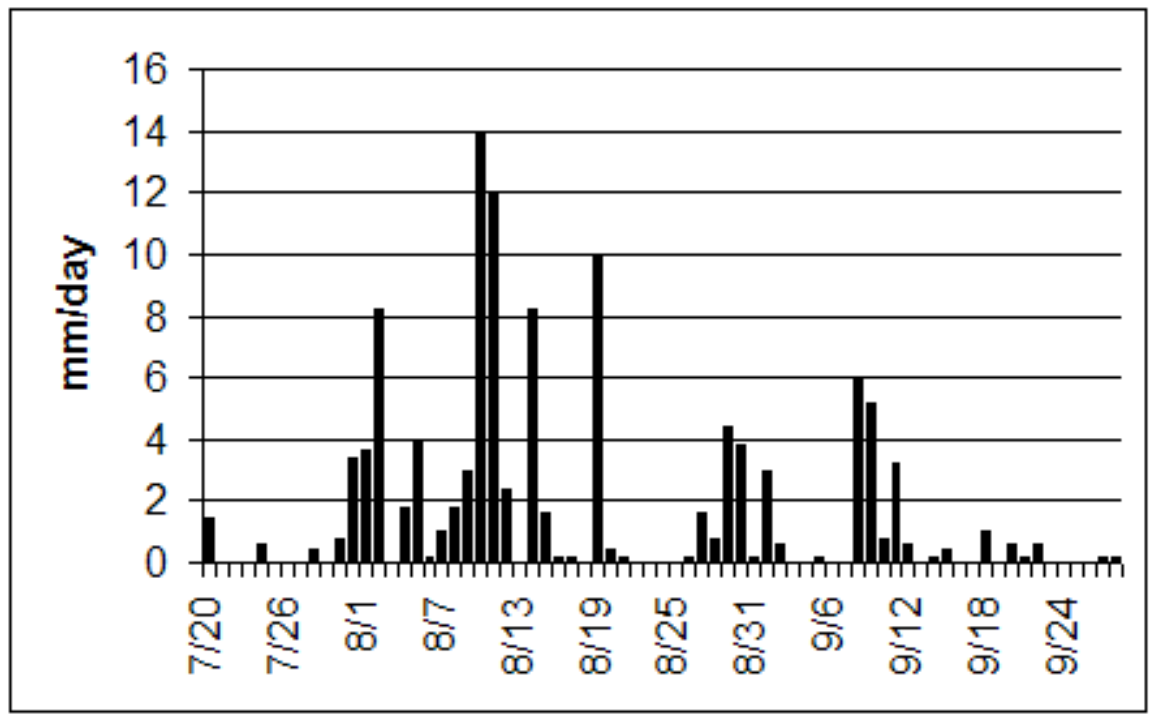

Fig. 7. Recorded precipitation at MFS

\section{Temperature}

The averaged daily water temperature decreased from $18{ }^{\circ} \mathrm{C}(19 / 7)$ to $8{ }^{\circ} \mathrm{C}$ (28/9), with a short warmer period at the end of August (Fig. 8). The daily temperature range reached $27{ }^{\circ} \mathrm{C}$ on $24 / 7$, expressing the typical continental climate in the centre of West Siberia. Frost occurred occasionally during August, becoming frequent in September.

\section{Waterlevels}

At 5 locations the water table level of mires has been recorded (Fig. 2). Upstream of the weir, in Western direction (see below), three sites have been instrumented. At two additional sites (p01, p08) devices have been installed in the peatland catchment area. The results have been plotted in Figure 8. The point p04 is located $1.7 \mathrm{~km}$ upstream of the weir, p03 at $1.1 \mathrm{~km}$ and $\mathrm{H} 02$ at 382 m. Points p01 and p08 are $0.25 \mathrm{~km}$ (North) respectively $0.3 \mathrm{~km}$ (South) from the weir. The water level variation is highly correlated between all points and clearly rose by precipitation events and descended in dry periods by evapotranspiration (Fig. 9). 


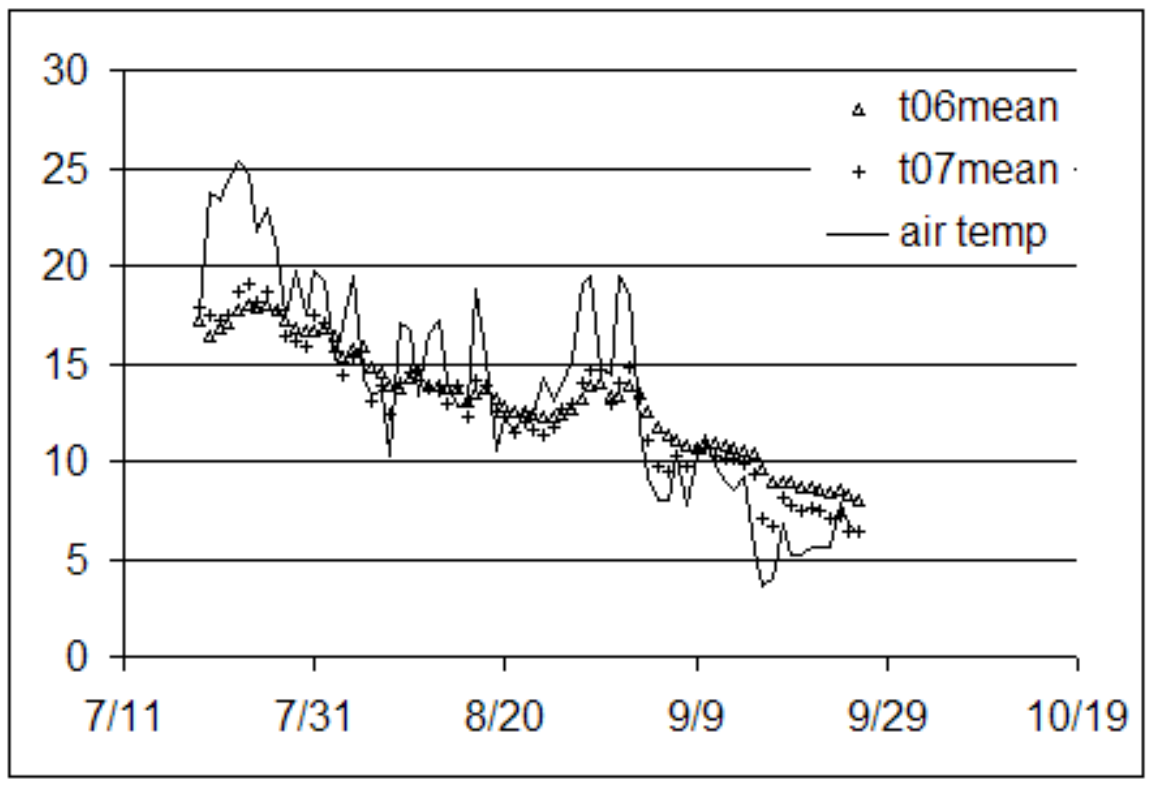

Fig. 8. Recorded temperature in ${ }^{\circ}$ C. Air temperature was logged by the Hobo device. The water temperature in the lysimeters (t07 and t06) was logged by the Divers

The water level variation at point p02 is small compared to the higher upstream points $\mathrm{p} 03$ and $\mathrm{p} 04$. Overland water flow toward the weir compensates evapotranspiration losses (p02). Highest water level variation occurred at site p01. This site is located in ryam mire. All other sites are in hollow mires. Moreover, the site p01 lies beyond the catchment area, nearer to the river valley and therefore subject to some desiccation. During dry periods the water table at p01 descends faster compared to the other sites, most probably caused by infiltration to the groundwater. The water level variation in the weir pond (p05) is an order smaller than at the upstream sites.

\section{Lysimeters}

In figure 10 the recorded water levels of both lysimeters is shown. The level in the lysimeter without vegetation (p07) varies much less compared to the lysimeter with hollow mire (p06). The water level in p07 rises during rain and descends in dry periods according evaporation. Because there is no water leaking, the water stage $(\mathrm{H})$ change in the lysimeter p07 can be modeled with Eq.2: 
$\Delta \mathrm{H} 07=\mathrm{P}-\mathrm{E}_{0} \quad\left(\mathrm{md}^{-1}\right)$

Eq.2

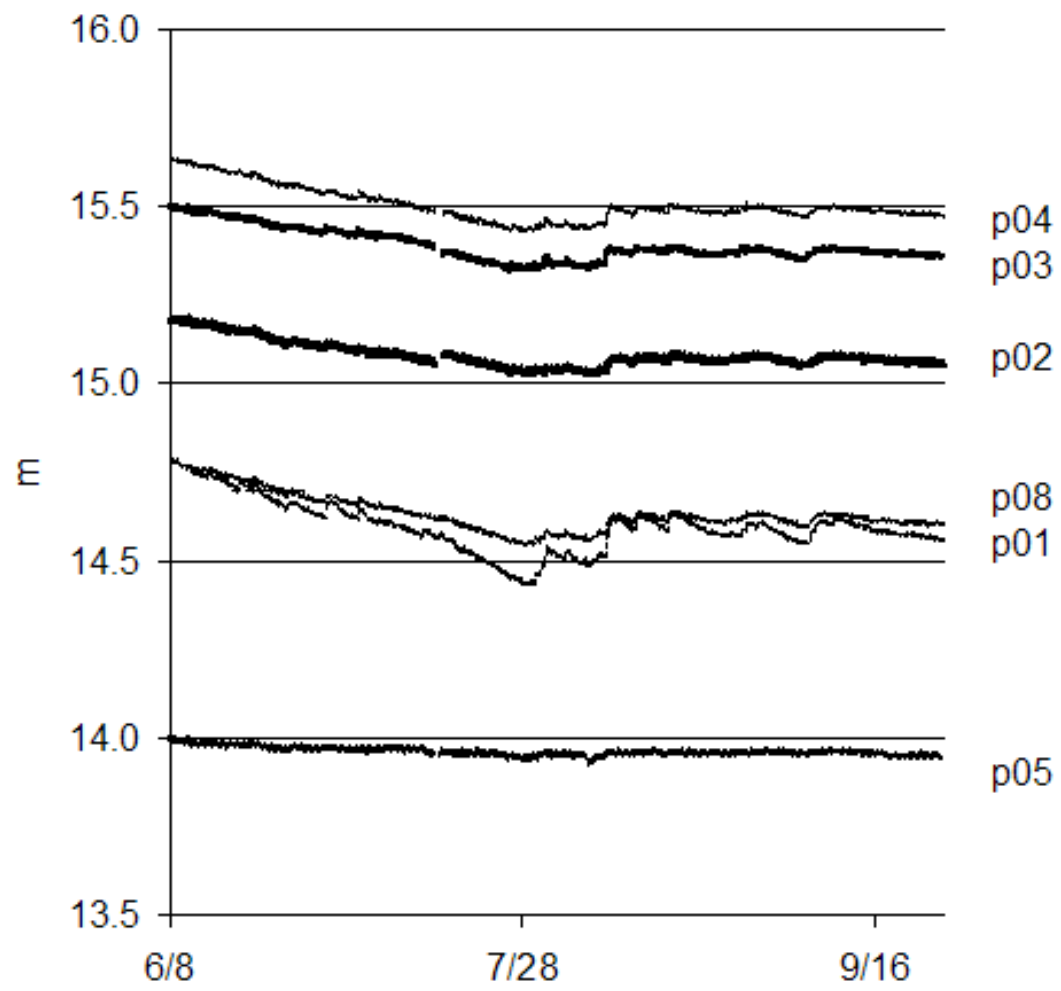

Fig. 9. Recorded water levels (half hour frequency). Y-as: water level above relative datum.

By interations while comparing the results of forward modeling starting at the beginning of the precipitation record, the evaporation $\left(\mathrm{E}_{0}\right)$ was determined at $0.9 \mathrm{mmd}^{-1}$. However, the dynamics of the water level in the lysimeter was not predicted satisfactory. Evaporation $\left(\mathrm{E}_{0}\right)$ depends on several parameters (radiation, heat flux, air moist, wind and more). During the 2008 campaign only temperature has been measured. For successive days without precipitation the water level in the lysimeter decreased with temperature (t07) of the water $\left(\Delta \mathrm{H} 07=0.0377 * \mathrm{t} 07, \mathrm{r}^{2}: 0.31, \mathrm{~N}: 16\right)$. Therefore we added a normalized temperature factor (nt) to the lysimeter model (Eq. 3):

$$
\Delta \mathrm{H} 07=\mathrm{P}-\mathrm{nt} \cdot \mathrm{E}_{0} \quad\left(\mathrm{md}^{-1}\right)
$$


where: $\mathrm{nt}_{\mathrm{p}}=\mathrm{t}_{\mathrm{p}} /$ average $\left(\mathrm{t}_{\mathrm{p}}\right), \mathrm{t}_{\mathrm{p}}$ : temperature in lysimeter, average $\left(\mathrm{t}_{\mathrm{p}}\right)$ covers the modeled period only.

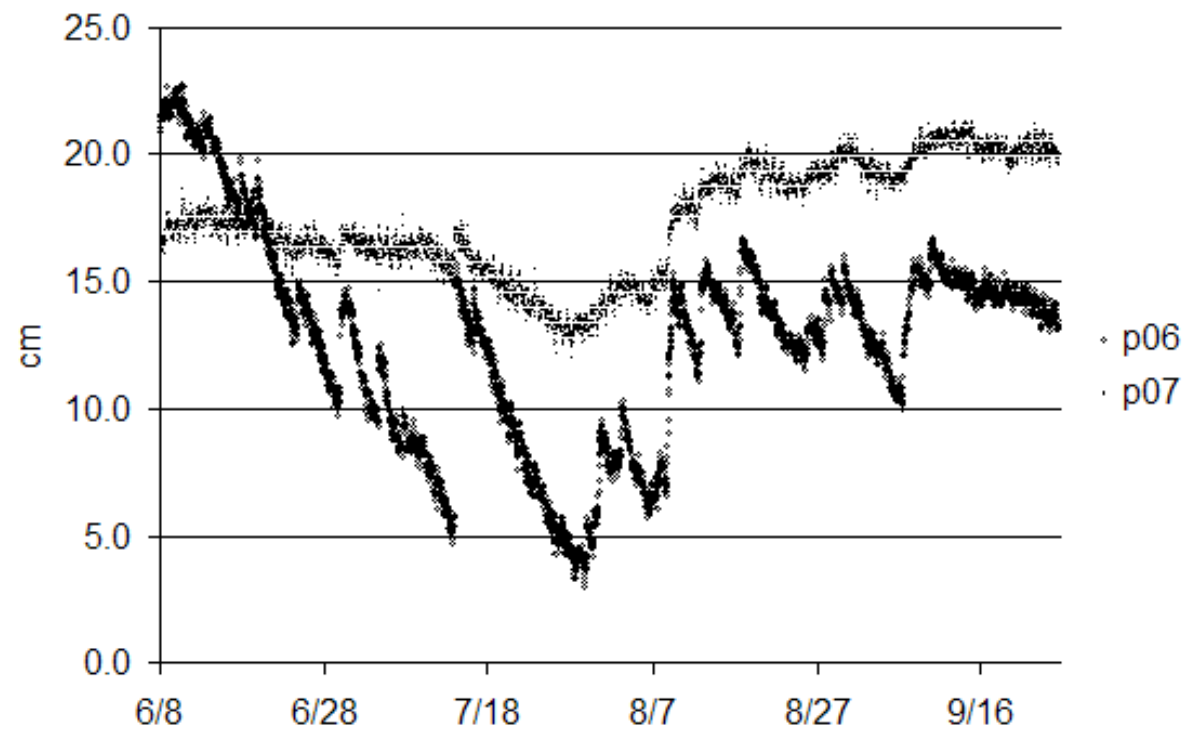

Fig. 10. Water stages inside the lysimeters (half hour frequency). Diver records p07(gray dots): with water; p06 (black dots): with 'hollow mire'. The water level in lysimeter p06 has adjusted on day 14/7.

The results of this model, together with the measured water level variation is presented in Fig. 11.

The water level in the lysimeter with hollow mire (p06) rises and descends steeper compared to the lysimeter with water only. These differences are caused by porosity of the acrotelm. Input of rainwater leads to a water level change inside the lysimeter (H06) according:

$$
\Delta \mathrm{H} 06=\left(\mathrm{P}-\mathrm{I}-\mathrm{nt} \cdot \mathrm{E}_{0}\right) / \eta \quad\left(\mathrm{md}^{-1}\right) \quad \text { Eq.4 }
$$

whith $\eta: \mathrm{a} \cdot \mathrm{e}^{\mathrm{b} \cdot \mathrm{H} 06}$

where $\eta$ : effective porosity at depth $\mathrm{H} 06$ (H06: recorded water stage in $\mathrm{m}$ above a local reference level); $a, b$ are constants;

$\mathrm{I}$; interception (see text). 


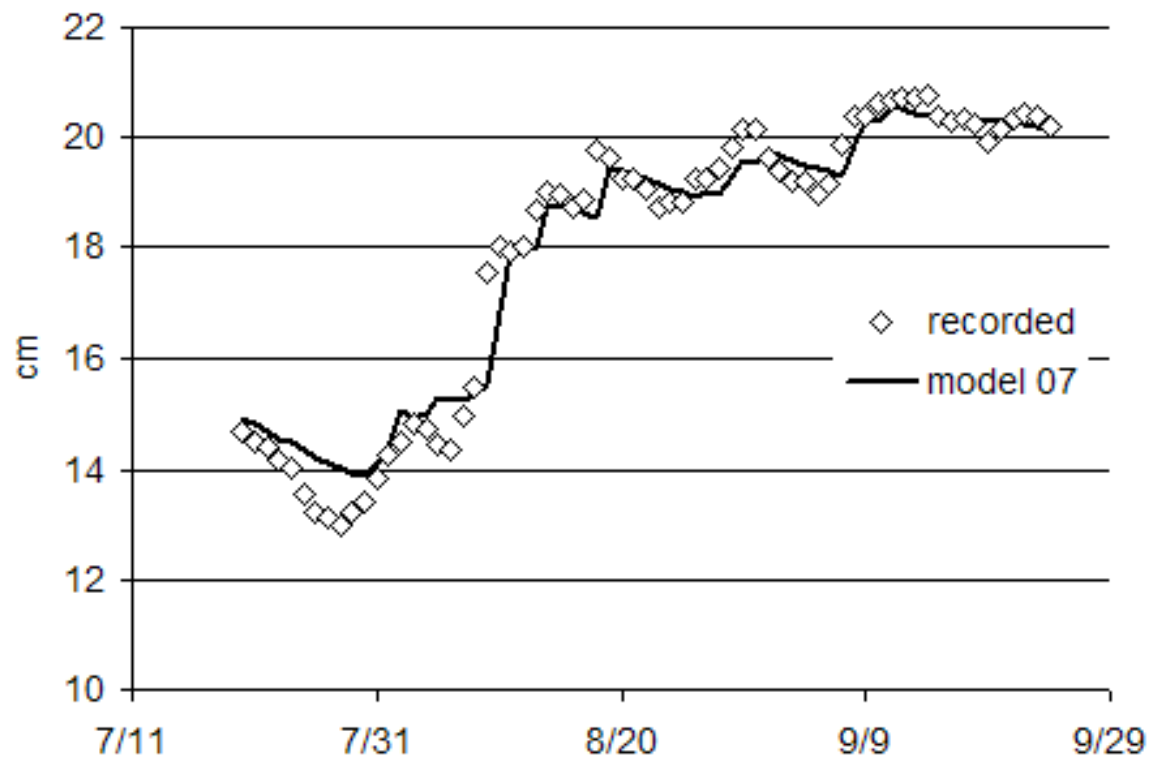

Fig. 11. Recorded and modeled water stage inside lysimeter p07 (water only).

Effective porosity of the acrotelm layer varies in depth by increasing density of (dead) moss stems, roots, etc. From the moss surface $\left(\eta_{0}=1\right)$ porosity exponentially decreases downward to the acrotelm. This means that the enhancement of a rise (by rain input) or of a descent (by evapotranspiration) by effective porosity is depth defined. The porosity constants (a, b in Eq 4) have been established by iterations. In Fig. 12 the vertical distribution of porosity in the lysimeter vegetation mat ("y06") is shown.

Interception is dependent on the already captured volume of water ( $\mathrm{I}_{\mathrm{vol}}$ : in $\mathrm{md}^{-1}$ ) and the maximum amount of water, which can be captured in the acrotelm layer of the vegetation $\left(I_{\max }\right)$. If precipitation is less than $I_{\max }-I_{\mathrm{vol}}$ all rain will be captured. If more rain comes, the amount above $I_{\max }$ will percolate downward to the saturated zone and affect the water level. A part $\left(\mathrm{E}_{\mathrm{int}}\right)$ of the intercepted water $\left(\mathrm{I}_{\mathrm{vol}}\right)$ will evaporate or is used by mosses and plants for transpiration. In the model the value of $E_{\text {int }}$ is set in a way that ultimately all $I_{v o l}$ will be used. In effect, the total evapotranspiration (over longer periods) is the 
sum of the open water evaporation $\left(\mathrm{E}_{0}\right)$ and interception-evapotranspiration $\left(\mathrm{E}_{\text {int }}\right)$.

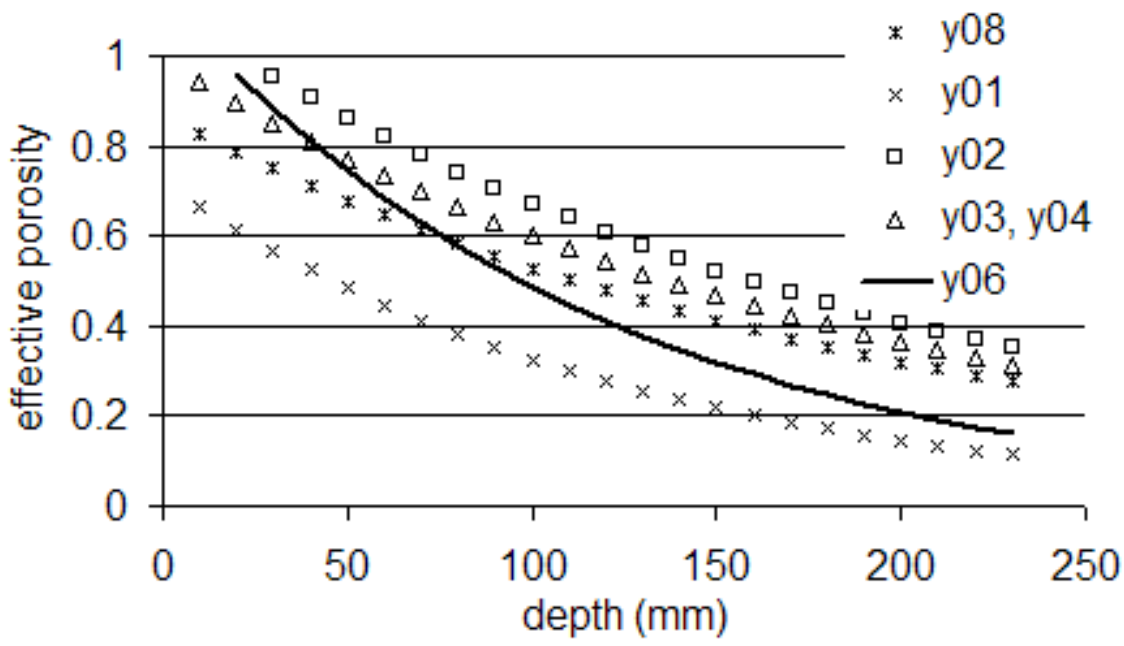

Fig. 12. Computed effective porosity (y) by depth for all locations

The result of forward modeling with Eq 4, starting from June $21^{\text {st }}$ using recorded precipitation data and open water evaporation $\left(\mathrm{E}_{0}\right)$ from lysimeter p07, is depicted in Fig. 13 together with the recorded water level. A one day delay in the model outcome typically results from the modeling procedure. The highest and lowest recorded water levels have been predicted rather well. The model results of the slopes of rising and falling water level are comparable, though less good in the second half of August.

Table 1. Model parameters used for Interception (mm). Imax: maximum volume of captured precipitation water, Eint: evapotranspiration of interception water.

\begin{tabular}{|c|c|c|c|c|c|c|}
\hline & model 06 & model 01 & model 08 & model 02 & model 03 & model 04 \\
\hline Imax & 3.00 & 2.50 & 6.00 & 4.00 & 3.00 & 3.90 \\
\hline Eint & 0.35 & 1.00 & 0.26 & 0.35 & 0.35 & 1.00 \\
\hline
\end{tabular}




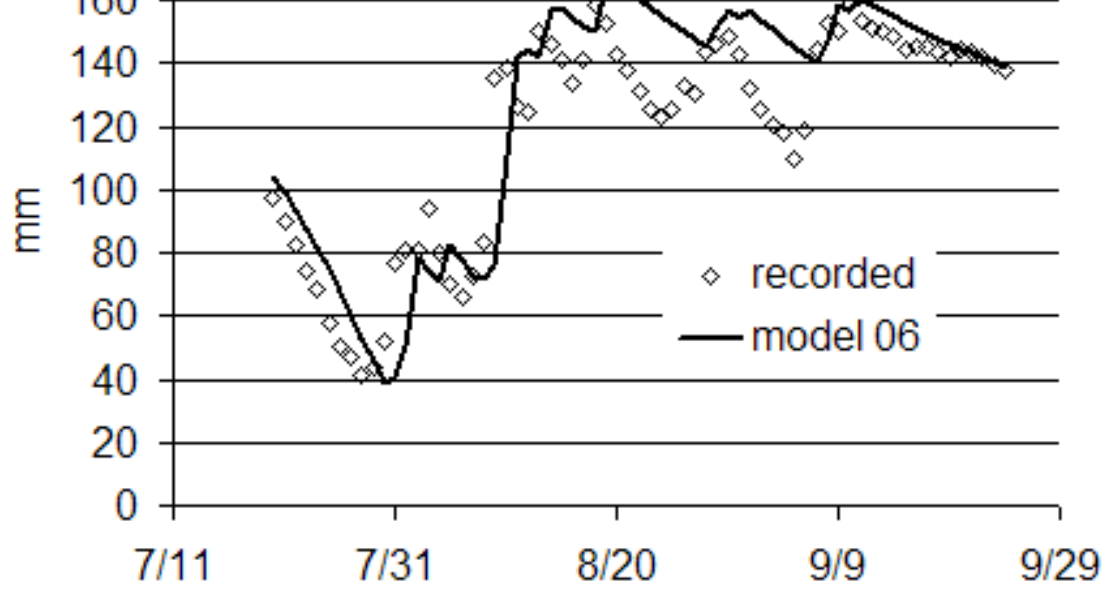

Figure 13. Recorded and modeled water stage inside lysimeter p06 (with mire)

\section{Discharge}

From the recorded stages (p05) the daily water discharge passing the weir has been calculated (Fig. 15). The first part of the recordings (10/06 16/07) show the effect of snowmelt, which probably started at the end of May.

The period 10/8 - 21/9 has been used to calculate the probable surface area of the mire catchment area. This was done by dividing the discharge sum by the sum of all net precipitation (Eq. 4) of the same period. By this method the total area was $2.6 \mathrm{~km}^{2}$.

\section{Conclusions and recommendations}

The first measurements have been used to calculate rather successfully the evapotranspiration, interception and surface area from the mire catchment area. Of the average precipitation of 1.69 mmday $^{-1}$ (period 22/7 - 26/9) remained 1.19 mmday $^{-1}$ for overland flow and groundwater recharge as a result of evapotranspiration of the intercepted water volume of about 0.5 mmday $^{-1}$. 

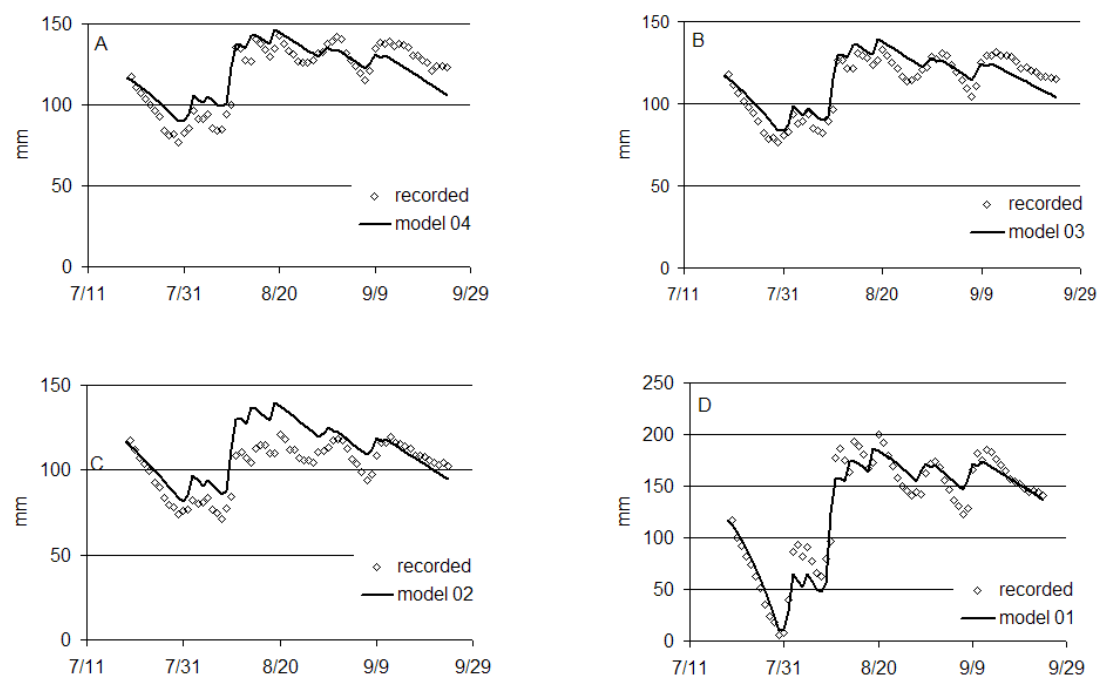

Fig. 14. Recorded and modeled water levels at sites A: p04; B:p03; C:p02; D:p01. Water depth in mm above the pressure sensor.

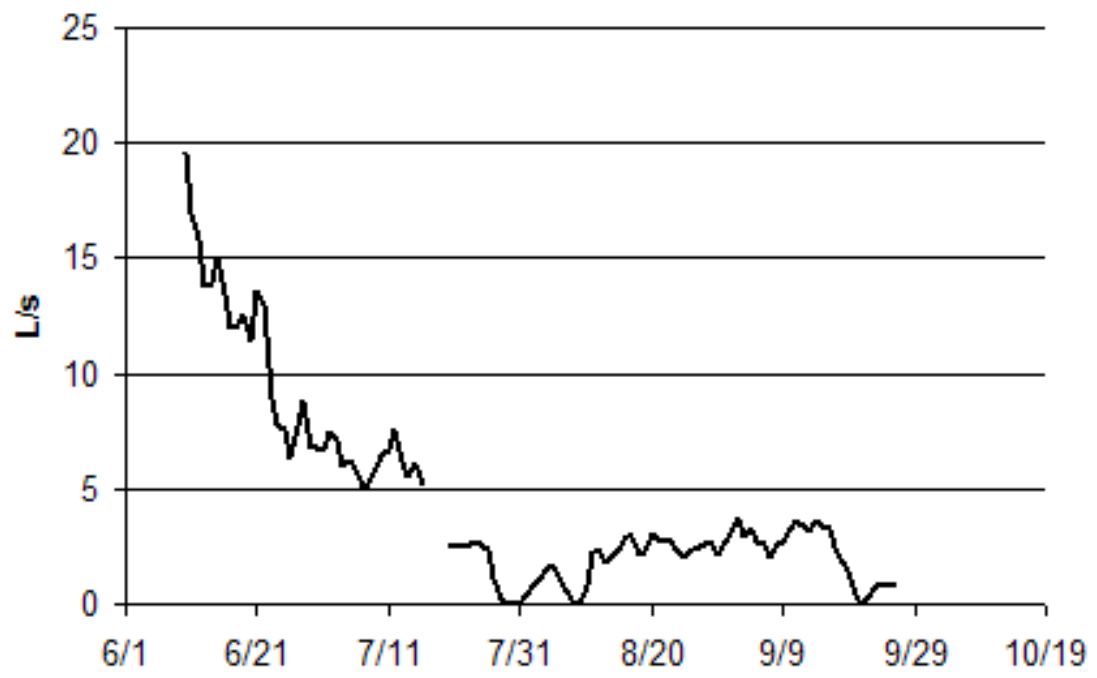

Fig. 15. Water discharge at the weir. 
However, the number of sites was limited and the period of measurements did not cover the whole season. Mainly by a defect rain gage most of the data of June-not be used.

The discharge of a period between 2 moments of zero water discharge over the weir, the net precipitation sum predicted the surface area of the catchment area to be within the expected size

The retention of rainwater seemed to be lower than expected. No strong 'sponge effect' could be established.

Snow depth was not measured and spring water discharge was not recorded well enough to model snowmelt water discharge, which is obviously the most important in discharge dynamics.

In further hydrological research at the Mukhrino Field Station the spatial distribution of snow depth should be measured before the snowmelt starts. The elaboration of the data, including 1 dimensional modelling of water stage dynamics was dependent on one rain gauge. In future research at least three gauges should be installed, because it has been proved recently that the differences between 2 gauges (in the same site) can be up to $10 \%$.

The installation of an eddy-covariance tower in the catchment area can be of great help for improvement the data of actual evapotranspiration, which data are the mosty uncertain part in hydrological research.

The next step in hydrological research will be the development of a 3Dimensional discharge model (Borren \& Bleuten, 2006), for improved prediction of the discharge dynamics. Hereto additional elevation measurements should be performed and a digital elevation model (DEM) will be prepared. A land unit mapping at high resolution (meter scale) shall be made as well. 


\section{References}

Eppinga M.B., Rietkerk M., Borren W., Lapshina E.D., Bleuten W., Wassen M.J. 2008 // Ecosystems, 11, 520-536, doi: 10.1007/s10021-008-9138-z.

Borren W., Bleuten W. 2006 // Water Resour. Res., 42,W12413 13p.

Bleuten W., Borren W., Glaser P.H., Imaizumi M., Ishida S., Lapshina E.D., Mäkilä M., Säävuori H., Siegel D., Tsuchihara T., Wassen M. 2006. Hydrological processes, nutrient flows and patterns of fens and bogs // Wetlands and Natural Resource Management / Bobbink R., Beltman B., Verhoeven J.T.A., Whigham D.F. (eds.). Ecological Studies, 190. - New York: Springer Verlag. - 184-204.

Ivanov K.E. 1981. Water movement in mirelands (Vodoobmen v bolotnykh landshaftakh, in Russian) Translated by Thgomson A. Ingram. HA. London: Academic Press. 


\title{
ГИДРОЛОГИЯ БОЛОТНЫХ ЭКОСИСТЕМ ЦЕНТРАЛЬНОЙ ЧАСТИ ЗАПАДНОЙ СИБИРИ: ПОЛЕВАЯ СТАНЦИЯ «МУХРИНО»
}

\author{
Блейтен В., Филиппов И.
}

Гидрология болот (ненарушенных экосистем торфяников) с трудом поддается количественному анализу. Основное предположение, используемое при количественном описании гидрологии болот, состоит в том, что болота могут сохранять воду, поступившую с сосадками («эффект губки»). Но это предположение никогда не было доказано на основе экперементальных полевых данных. Недостающие данные, не позволяющие проверить указанное предположение, суть: влагопроводность, водопроницаемость, фактическое испарение и перехват воды осадков как мхами на поверхности, так и торфом более глубоких слоев.

Только что созданная полевая станция «Мухрино», расположенная в центральной части Западной Сибири на окраине гигантского болотного комплекса, предоставила благоприятную возможность начать количественные гидрологические исследования. Совместное использование датчиков давления и лизиметров вкупе с одновременным измерением количества осадков, температуры воздуха и воды позволило анализировать динамику уровня стояния воды в болотах, испарение, перехват воды осадков мхами и торфом, а также водный баланс.

В нашей работе представлены первые результаты, следующие из данных, полученных в летний сезон 2008 г. Было осуществлено одномерное моделирование процесса, кажущегося наиболее важным в плане потери воды в болоте - перехвата осадков мхами и нижележащим торфом. Как и ожидалось, динамика стока воды на изучаемом болоте определяется главным образом таянием снега. Осадки в виде дождя дают относительно быстрый отклик стока. Так называемый «эффект губки» не был обнаружен в наших исследованиях.

Дальнейшие исследования будут сфокусированы на трехмерном моделировании взаимосвязи между типом ландшафта («типом болота») и динамикой стока. 